\title{
І.Г. Криворчук, І.М. Лещишин
}

\section{Корекція стресової гіперглікемії в хірургічних пацієнтів із метаболічним синдромом}

\author{
Олександрівська клінічна лікарня, м. Київ, Україна \\ Ukrainian Journal of Perinatology and Pediatrics. 2020. 3(83): 26-30; doi 10.15574/PP.2020.83.26 \\ For citation: Kryvorchuk IG, Leshchishin IM. (2020). A Correction of stress hyperglycemia in surgical patients with metabolic syndrome. \\ Ukrainian Journal of Perinatology and Pediatrics. 3(83): 26-30. doi 10.15574/PP.2020.83.26
}

Враховуючи, що стресова і діабетична гіперглікемія є незалежним фактором ризику зростання летальності у хірургічних пацієнтів з метаболічним синдромом, збільшення термінів перебування пацієнтів у відділеннях реанімації і інтенсивної терапії та вартості лікування, важливим є проведення лікування, зокрема інфузійної терапії з призначенням препаратів, які не підвищують рівень глюкози та сприяють зниженню потреби в інсуліні у пацієнтів з цукровим діабетом в післяопераційному періоді.

Мета - вивчити ефективність препарату Ксилат як складового компоненту інтенсивної терапії пацієнтів із метаболічним синдромом у періопераційному періоді.

Матеріали та методи. Дослідження проведено у 21 жінки з метаболічним синдромом, яким виконане ургентне хірургічне втручання з приводу пухлин у ділянці малого тазу. Усім пацієнткам введено препарат Ксилат (Юрія-Фарм) - 5-6 мл/кг/добу 50-70 крапель/хв упродовж 3 днів післяопераційного періоду. Контрольну групу становили 15 жінок із метаболічним синдромом, які пройшли хірургічне лікування в обласній клінічній лікарні 3 приводу пухлин яєчників, але отримали альтернативну інфузійну терапію в післяпопераційному періоді (за даними архівних історій хвороби).

Результати. За результатами дослідження, препарат Ксилат (Юрія-Фарм) сприяє зниженню ризику виникнення тяжкості стресової гіперглікемії, пригнічує ризик фрормування лактацидемії, чинить енергетичну підтримку післяопераційних хворих із цукровим діабетом 3 незалежним від інсуліну метаболізмом, стимулює вироблення ендогенного інсуліну в пацієнтів у критичному стані.

Висновки. На тлі застосування Ксилату підвищується толерантність до вуглеводів. Він має дуже низький глікемічний індекс, антикетогенні властивості, не чинить несприятливої дії на центральну нервову систему, обмін гормонів і нейротрансміттерів.

Дослідження виконано відповідно до принципів Гельсінської Декларації. Протокол дослідження ухвалено Локальним етичним комітетом зазначеної в роботі установи. На проведення досліджень отримано інсрормовану згоду жінок.

Автори заявляють про відсутність конфллікту інтересів.

Ключові слова: хірургічні пацієнти, цукровий діабет, гіперглікемія, інфузійна терапія, метаболічний синдром, Ксилат.

\author{
Correction of stress hyperglycemia in surgical patients with metabolic syndrome \\ I.G. Kryvorchuk, I.M. Leshchishin \\ Alexandrovskiy clinical hospital, Kyiv, Ukraine \\ Bogomolets National Medical University, Kyiv, Ukraine
}

Taking into account that stress and diabetic hyperglycemia is an independent risk factor for increased mortality in surgical patients with metabolic syndrome, an increase in the time spent by patients in intensive care units and the cost of treatment, it is important to carry out treatment, in particular, infusion therapy with the appointment of drugs that do not increase glucose levels and help to reduce the need for insulin in patients with diabetes mellitus in the postoperative period. Aim is to assess the effectiveness of the drug Xylat as an integral component of intensive care for patients with metabolic syndrome in perioperative period. Materials and methods. The study was conducted in 21 women with metabolic syndrome who underwent urgent surgical intervention for tumors in pelvic area. All patients received Xylat (Yuria-Pharm) - 5-6 ml/kg/day, 50-70 drops/min for 3 days in the postoperative period. The control group consisted of 15 women with metabolic syndrome, who underwent surgical treatment in the regional clinical hospital for ovarian tumors, but received alternative infusion therapy during the postoperative period (according to archived case histories)

Results. The data of our study showed that the drug Xylatum (Yuria-Pharm) helps to reduce the risk of the severity of stress hyperglycemia, suppresses the risk of lactacidemia, provides energy support for postoperative patients with diabetes mellitus with an insulin-independent metabolism, and stimulates the production of endogenous insulin in critically ill patients.

Conclusions. With the use of Xylate, the tolerance to carbohydrates increases. It has a very low glycemic index, antiketogenic properties, does not adversely affect the central nervous system, the exchange of hormones and neurotransmitters.

The research was carried out in accordance with the principles of the Helsinki Declaration. The study protocol was approved by the Local Ethics Committee of these Institutes. The informed consent of the patient was obtained for conducting the studies.

No conflict of interest was declared by the authors.

Key words: surgical patients, diabetes mellitus, hyperglycemia, infusion therapy, metabolic syndrome, Xylatum.

\section{Коррекция стрессовой гипергликемии у хирургических пациентов с метаболическим синдромом и.Г. Криворчук, И.М. Лещишин \\ Александровская клиническая больница, г. Киев, Украина \\ Национальный медицинский университет имени А.А. Богомольца, г. Киев, Украина}

Учитывая, что стрессовая и диабетическая гипергликемия является независимым фактором риска роста летальности у хирургических пациентов с метаболическим синдромом, увеличения времени пребывания пациентов в отделениях реанимации и интенсивной терапии и стоимости лечения, важным является проведение лечения, в частности инфузионной терапии с назначением препаратов, которые не повышают уровень глюкозы и способствуют снижению потребности в инсулине у пациентов с сахарным диабетом в послеоперационном периоде.

Цель - изучить эффрективность препарата Ксилат в качестве составляющего компонента интенсивной терапии пациентов с метаболическим синдромом в периоперационном периоде.

Материалы и методы. Исследование проведено у 21 женщины с метаболическим синдромом, которым выполнено ургентное хирургическое вмешательство по поводу опухолей в области малого таза. Всем пациенткам введен препарат Ксилат (Юрия-Фарм) - 5-6 мл/кг/сутки 50-70 капель/мин в течение 3 дней послеоперационного периода. Контрольную группу составили 15 женщин с метаболическим синдромом, которые прошли хирургическое лечение в областной клинической больнице по поводу опухолей яичников, но получили альтернативную инфузионную терапию в послеоперационном периоде (по данным архивных историй болезни).

Результаты. По данным исследования, препарат Ксилат (Юрия-Фарм) способствует снижению риска возникновения тяжести стрессовой гипергликемии, подавляет риск формирования лактацидемии, оказывает энергетическую поддержку послеоперационных больных с сахарным диабетом с независимым от инсулина метаболизмом, стимулирует выработку эндогенного инсулина у пациентов в критическом состоянии.

Выводы. На фоне применения Ксилата повышается толерантность к углеводам. Он имеет очень низкий гликемический индекс, антикетогенные свойства, не оказывает неблагоприятного воздействия на центральную нервную систему, обмен гормонов и нейротрансмиттеров.

Исследование выполнено в соответствии с принципами Хельсинской Декларации. Протокол исследования утвержден Локальным этическим комитетом указанного в работе учреждения. На проведение исследований получено информированное согласие женщин.

Авторы заявляют об отсутствии конфрликта интересов.

Ключевые слова: хирургические пациенты, сахарный диабет, гипергликемия, инфузионная терапия, метаболический синдром, Ксилат. 
$\mathrm{B}_{\mathrm{i}}^{\mathrm{i}}$ домо, що метаболічний синдром діагностується в кожного п'ятого в популяції і становить небезпеку порушення всіх видів обміну (вуглеводного, жирового, мінерального), виникнення цукрового діабету 2-го типу, гіпертонічної хвороби, атеросклерозу, розвитку інфаркту й інсульту, появи проблем опорнорухового і зв'язкового апарату, пошкодження суглобів і хребта тощо. Ризик розвитку інфаркту й інсульту збільшується в 6-7 разів порівняно $з$ пацієнтами без метаболічного синдрому.

Ключовою ланкою метаболічного синдрому $€$ первинна інсулінорезистентність і компенсаторна гіперінсулінемія та гіперглюкоземія. Гіперінсулінемія будь-якого походження призводить до формування інсулінорезистентності, генерує і підтримує резистентність до інсуліну незалежно від основної патології. У хірургічних пацієнтів із метаболічним синдромом також спостерігається підвищений рівень маркерів запалення, включаючи цитокіни і C-реактивний білок, що ще більше спричиняє виникнення ускладнень [9].

3 іншого боку, існують доказові дані щодо виникнення стресової гіперглікемії в хірургічних хворих та іiі несприятливого впливу на організм пацієнтів. Стресова гіперглікемія супроводжує безліч критичних станів організму людини і безпосередньо пов'язана 3 підвищеною летальністю [3]. Стресова і діабетична гіперглікемія ідентифікована як незалежний фактор ризику зростання летальності, подовження термінів перебування пацієнтів у відділеннях інтенсивної терапії.

Останнім орієнтиром цільового рівня глікемії для хірургічних пацієнтів, які перебувають у відділеннях інтенсивної терапії, є концентрація в межах 7,7-10 ммоль/л. Це приводить до зниження як летальності, так і кількості ускладнень у хірургічних хворих [10].

За результатами досліджень, підвищення рівня глюкози не становить значного ризику, якщо рівень лактату не підвищений [8]. Отже, необхідною є корекція стресової гіперглікемії для зниження рівня летальності не введенням інсуліну, а іншими препаратами, оскільки додаткові дози інсуліну сприяють зростанню показника лактату за умови наявності інсулінорезистентності $[4,6]$.

Гіперглікемія і порушення толерантності до глюкози супроводжують періопераційний стрес у хірургічних хворих. А враховуючи наявність метаболічного синдрому, суттєво збільшується негативний вплив інсулінорезистентності й гіперглікемії. Гіперглікемія підвищує осмолярність і призводить до клітинної дегідратації, порушень електролітного і кислотно-лужного обміну. Підвищена продукція лактату зумовлює ацидоз, гіпокаліємію, гіпонатріємію з надмірним виведенням останніх через нирки. Через порушення водного та електролітного обміну виникають різні порушення з боку серцево-судинної системи (тахікардія, гіпотонія, аритмії) [8].

У критичних станах в умовах гіперметаболізму і значного збільшення потреби в енергії істотно змінюється обмін вуглеводів. Починається активний розпад глікогену з викидом глюкози в кров і розвитком гіперглікемії. При цьому посилюється як аеробний, так і анаеробний гліколіз. У разі аеробного гліколізу збільшується утворення вуглекислого газу, що веде до ацидозу і порушення дихальної функції. Виділення підвищеної кількості $\mathrm{CO}_{2}$ легенями може збільшувати навантаження на органи дихання в пацієнтів після операцій, особливо в тих, які перебувають на продовженій вентиляції легенів або мають дихальну недостатність.

У періопераційному періоді закономірно збільшуються витрати енергії в спокої пацієнта на 5-10\%, а в разі інфекційних ускладнень (періоніт) - енерговитрати спокою підвищуються до 50\%.

Основним завданням передопераційної підготовки у хворого з метаболічним синдромом є корекція вуглеводного обміну, гіпой гіперволемічних станів, за можливості - компенсація функції нирок, профілактика інфекційних ускладнень.

У критичних станах аеробне окислення глюкози може супроводжуватися підвищеним утворенням $\mathrm{CO}_{2}$ i розвитком ацидозу. Тому в цих умовах найкращим може стати окислення жирних кислот і анаеробний розпад глюкози. Багатоатомні спирти не призводять до підвищення рівня глюкози в крові.

Проблема гіперглікемії внаслідок зниження толерантності до глюкози в пацієнтів у станах, асоційованих із тяжким стресом, а також проблема профілактики надлишкового введення інсуліну в таких хворих закономірно диктують необхідність застосування субстратів у складі енергетичної підтримки, метаболізм яких не залежить від інсуліну [1].

Потенційно несприятливі наслідки гіперінсулінемії можуть бути скореговані за допомогою введення багатоатомних спиртів (поліолів), важливе місце серед яких посідає ксиліт. Гіперактивація аеробного гліколізу, яка супрово- 
джує періопераційний період у хірургічних пацієнтів, пригнічується призначенням препарату Ксилат [2,5,7].

Дослідження на людях показали швидкий метаболізм Ксилату, менший вплив на концентрацію глюкози в крові, підвищену ефективність щодо збереження білка в організмі, зниження печінкової функції глюконеогенезу, антикетогенний ефект та менш пошкоджуючий ефект на вени. Таким чином, парентеральні розчини Ксиліту можуть бути особливо корисними для хірургічних пацієнтів із метаболічним синдромом на етапі інтенсивної терапії.

Ксилат після внутрішньовенного введення швидко розподіляється в організмі і не впливає на рівень глюкози в крові, оскільки його утилізація не залежить від інсуліну.

Ще 10 років тому в інтенсивній терапії широко використовувалися розчини глюкози. На сьогодні застосування розчинів глюкози в пацієнтів у середньотяжкому і критичному станах суттєво обмежене через ймовірність дегідратації клітин, підвищення продукції $\mathrm{CO}_{2}$ і лактату (останній збільшується на 80-85\% у критичних хворих), збільшення тканинної ішемії та головного мозку, можливість трансформування глюкози в джерело токсинів при порушенні гемодинаміки. Повністю відмовилися в сучасних клініках від рутинного використання глюкози для відновлення об'єму циркулюючої крові. За певними показаннями замість розчинів глюкози ефективним є введення препарату Ксилат.

Mema дослідження - вивчити ефективність препарату Ксилат як складового компоненту інтенсивної терапії пацієнтів із метаболічним синдромом у періопераційному періоді.

\section{Матеріали та методи дослідження}

Дослідження проведено у 21 жінки з метаболічним синдромом, яким виконане ургентне

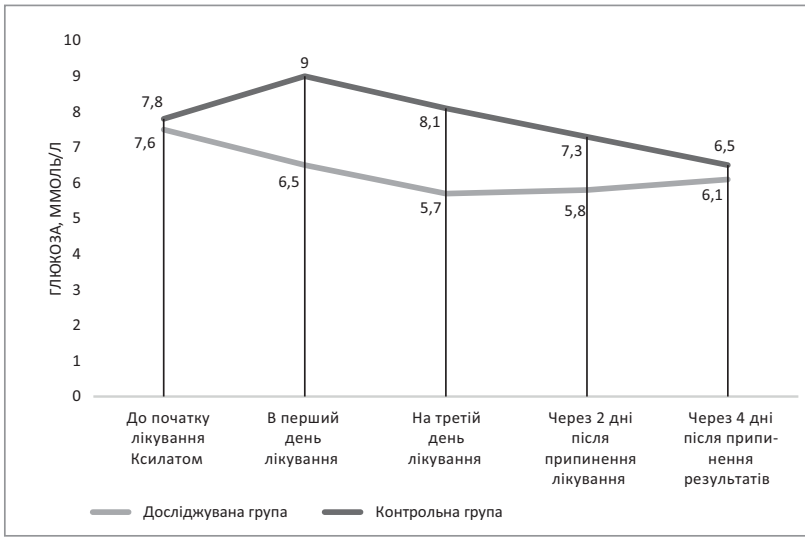

Рис. 1. Рівень глікемії до і після призначення препарату Ксилат (Юрія-Фарм) у групах досліджуваних жінок, p<0,05 хірургічне втручання 3 приводу пухлин у ділянці малого тазу. Серед них у 17 (80,9\%) жінок показаннями до операції були великі пухлини яєчників. У 4 (19,1\%) жінок діагностували об'ємні утворення кишечника. Слід зазначити, що $8(38,1 \%)$ хворих мали діагноз цукровий діабет 2-го типу, 6 (28,6\%) - цукровий діабет 1 -го типу, а $18(85,7 \%)$ - гіпертонічну хворобу. Усім пацієнткам введено препарат Ксилат (Юрія-Фарм) - 5-6 мл/кг/добу 50-70 крапель/хв упродовж 3 днів післяопераційного періоду. Контрольну групу становили 15 жінок iз метаболічним синдромом, які пройшли хірургічне лікування в обласній клінічній лікарні з приводу пухлин яєчників, але отримали альтернативну інфузійну терапію в післяопераційному періоді (за даними архівних історій хвороби).

Дослідження виконано відповідно до принципів Гельсінської Декларації. Протокол дослідження ухвалено Локальним етичним комітетом зазначеної в роботі установи. На проведення досліджень отримано інформовану згоду жінок.

\section{Результати дослідження та їх обговорення}

За результатами дослідження виявлено суттєве зменшення рівня глюкози крові після початку лікування Ксилатом у пацієнтів у післяопераційному періоді. 3 рисунку 1 видно, що висхідний рівень гіпоглікеміі одразу в післяопераційному періоді був майже однаковим у досліджуваній і контрольній групах (7,6 ммоль/л і 7,8 ммоль/л відповідно). Після початку лікування Ксилатом суттєво знизилася глюкоземія в 1-й день лікування (6,5 ммоль/л) і на 3-й день лікування (5,7 ммоль/л). Навіть після припинення інфузійної терапії Ксилатом у досліджуваній групі відносно тривалий час спостерігався показник глюкози на рівні 5,7 ммоль/л за мінімальної корекції інсуліном. У жінок групи анамнестичного контролю показники глюкози крові становили 9 ммоль/л одразу після операції як прояв стресової гіперглікемії, незважаючи на адекватну корекцію інсуліном, що пояснюється наявністю стресового фактора - операції.

Враховуючи, що в пацієнтів із цукровим діабетом спостерігається порушення трофіки, а післяопераційна рана загоюється з певними труднощами, важливим є гіпоглікемічний вплив препарату Ксилат для корекції післяопераційної стресової гіперглікемії в пацієнтів із цукровим діабетом.

Відомо, що на тлі ургентного хірургічного втручання в пацієнтів виникає більше ускладнень. Вимірювання показника лактату крові є 
маркером тяжкості стану хворого та прогнозування результатів лікування. Високий показник лактату є прогностичною ознакою негативного результату через низьку енергетичну ефективність при анаеробному гліколізі в пацієнтів у періопераційному періоді.

У хірургічних пацієнтів із метаболічним синдромом, зокрема з цукровим діабетом, підвищення показника лактату пов'язане не з гіпоперфузією, а з порушенням обміну речовин.

За даними рис. 2, після лікування препаратом Ксилат спостерігалося зменшення показника лактату в досліджуваній групі порівняно 3 контрольною. Майже повна нормалізація показника лактату відмічалася на 3-й день лікування, що співпадало 3 3-ю добою післяопераційного періоду і було маркером позитивного результату хірургічного лікування.

Наводимо клінічний випадок. Пацієнтка М., 43 роки, госпіталізована до хірургічного відділення зі скаргами на виражений абдомінальний біль. При обстеженні звертало на себе увагу, що жінка надмірної маси тіла (ожиріння III ступеня). 3 анамнезу відомо, що жінка страждає на цукровий діабет 1-го типу впродовж 14 років. Звертали на себе увагу блідість шкірного покриву, виражена тахікардія (110 уд./хв), надмірна пітливість. В аналізі крові - гемоглобін 110 г/л, лейкоцити $13 \times 10^{9}$, ШОЕ - 36 мм/год, невеликий зсув формули вліво: паличкоядерних $-9 \%$, лімфоцитів - $13 \%$, сегментоядерних - 65\%, моноцитів 9\%, еозинофілів - 4\%. Під час біохімічного дослідження виявлено такі показники: АЛТ - 38 ммоль/л, АСТ - 42 ммоль/л, глюкоза крові 7,9 ммоль/л, лактат - 3,1 ммоль/л. У льтразвукове дослідження черевної порожнини показало велике об'ємне утворення, яке виходить 3 яєчника (кістому яєчника). Враховуючи середньотяжкий стан хворої, виражений больовий синдром з ознаками значної вегетативної реакції, наявність ознак запалення, жінку прооперували в ургентному порядку.

Під час операції вилучили об'ємне утворення великого розміру (рис. 3).

За результатом гістологічного дослідження встановили кістому яєчника. У післяопераційному періоді жінці призначили інфузійну терапію 3 додаванням препарату Ксилат (ЮріяФарм), антибіотикотерапію, антикоагулянтну терапію, антимікотичні препарати. У післяопераційному періоді комплексна інфузійна терапія з додаванням препарату Ксилат сприяла нормалізації показників крові, зокрема лактату і глю-

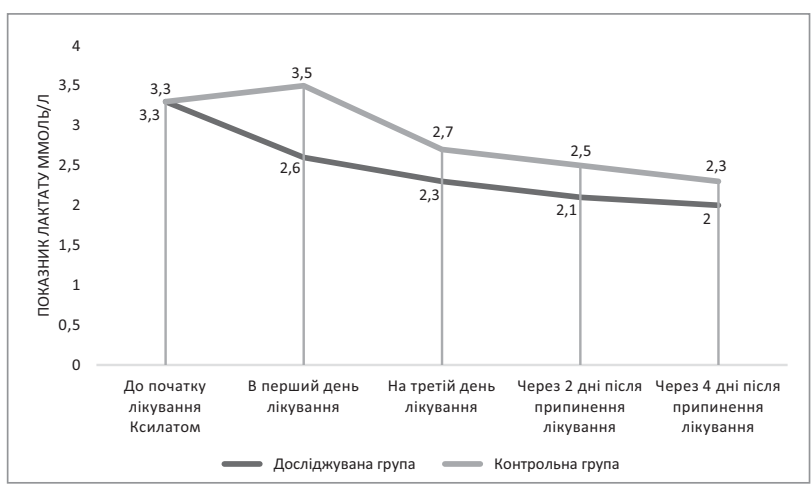

Рис. 2. Рівень лактату до та після лікування препаратом Ксилат (Юрія-Фарм) у досліджуваних групах, p<0,05

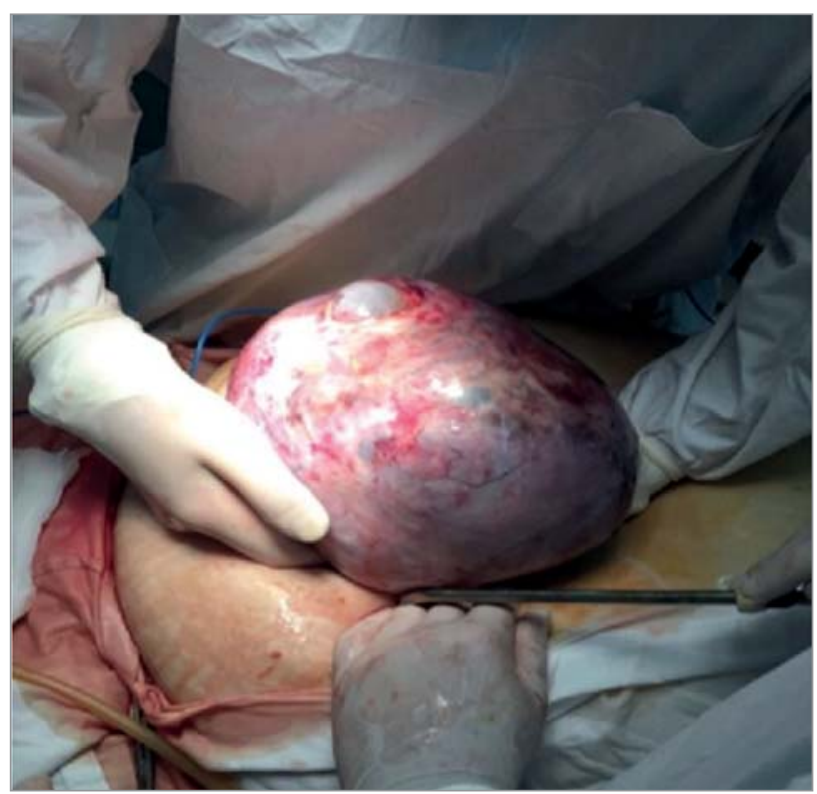

Рис. 3. Кістома яєчника

кози. Операційна рана загоїлась первинним натягом. Жінку виписали додому на 10-ту добу післяопераційного періоду.

\section{Висновки}

Враховуючи, що стресова і діабетична гіперглікемія є незалежним фактором ризику зростання летальності в хірургічних пацієнтів iз метаболічним синдромом, збільшення термінів перебування пацієнтів у відділеннях реанімації і інтенсивної терапії, а також вартості лікування, важливо проводити лікування, зокрема інфузійну терапію, 3 призначенням препаратів, що не підвищують рівня глюкози та сприяють зниженню потреби в інсуліні у пацієнтів із цукровим діабетом у післяопераційному періоді.

Підвищення показника лактату в хірургічних пацієнтів за наявності стресової гіперглікемії збільшує ризик летальності пацієнтів, а додаткове введення інсуліну в умовах форму- 
вання інсулінорезистентності сприяє збільшенню показника лактату. Вищезазначене доводить необхідність призначення препаратів, що дають змогу зменшити лактацидемію.

Препарат Ксилат (Юрія-Фарм) сприяє зниженню ризику виникнення тяжкості стресової гіперглікемії, пригнічує ризик формування лактацидемії, чинить енергетичну підтримку післяопераційних хворих із цукровим діабетом із незалежним від інсуліну метаболізмом, сти- мулює вироблення ендогенного інсуліну у пацієнтів у критичному стані.

На тлі застосування Ксилату підвищується толерантність до вуглеводів. Він має дуже низький глікемічний індекс, антикетогенні властивості, не чинить несприятливої дії на центральну нервову систему, обмін гормонів і нейротрансміттерів.

Автори заявляють про відсутність конфлікmy iнтересів.

\section{References/Література}

1. American Diabetes Association. (2007, Jan 30). Nutrition Recommendations and Interventions for Diabetes. A position statement of the American Diabetes Association. Diabetes Care. 1: 48-65. URL: https://doi.org/10.2337/dc07-S048.

2. Bar-Or D, Carrick M, Tanner A, Lieser MJ, Rael LT, Brody E. (2018, Feb) Overcoming the Warburg Effect: Is It the Key to Survival in Sepsis? Journal of Critical Care. 43: 197-201.

3. Bar-Or D, Rael LT, Madayag RM, Banton KL, Tanner II A, Acuna DL et al (2019, Mar 27). Stress Hyperglycemia in Critically III Patients: Insight Into Possible Molecular Pathways. Frontiers in Medicine: Intensive Care Medicine \& Anesthesiology. URL: https: //doi.org/10.3389/fmed.2019.00054.

4. Berhane F, Fite A, Daboul N, Al-Janabi W, Msallaty Z, Caruso M et al. (2015, Apr 19). Plasma Lactate Levels Increase during Hyperinsulinemic Euglycemic Clamp and Oral Glucose Tolerance Test. Journal of Diabetes Research. DOI: 10.1155/2015/102054.

5. Brault C, Zerbib Y, Delette C, Marc J, Gruson B, Marolleau JP et al. (2018, Jun 20). The Warburg Effect as a Type B Lactic Acidosis in a Patient with Acute Myeloid Leukemia: A Diagnostic Challenge for Clinicians. Frontiers in Oncology. 8: $232 . \mathrm{DOl}$ 10.3389/fonc.2018.00232.

6. Green JP, Berger T, Garg N, Horeczko T, Suarez A, Radeos MS et al. (2012, Nov 20). Hyperlactatemia Affects the Association of Hyperglycemia with Mortality in Nondiabetic Adults with Sepsis. Academic Emergency Medicine. 19 (11): 1268-1275. URL: https://onlinelibrary.wiley.com/doi/full/10.1111/acem.12015.

7. Natesan V. (2018, Feb). Adrenergic Blockade Inhibits Bacterial Quorum Sensing and Reverses Warburg Effect in Septic Shock. British Journal of Anaesthesia. 120 (2): 412-413. DOI: 10.1016/j.bja.2017.12.010.

8. Packer M. (2017, Oct 17). Activation and Inhibition of Sodium-Hydrogen Exchanger Is a Mechanism That Links the Pathophysiology and Treatment of Diabetes Mellitus With That of Heart Failure. Circulation. 136 (16): 1548-1559. URL: https://www.ahajournals.org/doi/pdf/10.1161/CIRCULATIONAHA. 117.030418.

9. Shanik MH, XuY, ?krha J, Dankner R, Zick Y, Roth J. (2008, Feb 31). Insulin Resistance and Hyperinsulinemia. Is hyperinsulinemia the Cart or the Horse? Diabetes Care. 2: 262-268. URL: https://doi.org/10.2337/ 208-s264.

10. Stapleton RD, Heyland DK. (2018, Jul 24). Glycemic Control and Intensive Insulin Therapy in Critical IIIness. UpToDate. URL: https://www.uptodate.com/contents/glycemic-control-and-intensive-insulin-therapy-incritical-illness.

Відомості про авторів:

Криворчук Ігор Григорович - к.мед.н., асистент каф. хірургії з курсом невідкладної та судинної хірургії НМУ імені О.О. Богомольця. Адреса: м. Київ, вул. Шовковична, 39/1

тел. (044)255-15-60.

Лещишин Іван Михайлович - к.мед.Н., доц. каф. хірургії з курсом невідкладної та судинної хірургії НМУ імені О.О. Богомольця. Адреса: м. Київ, вул. Шовковична, 39/1;

тел. (044)255-15-60.

Стаття надійшла до редакції 08.06.2020 р.; прийнята до друку 10.09.2020 p.

\section{УВАГА! ВАЖЛИВА ІНФОРМАЦІЯ!}

\section{Зміни в оформленні списку літератури}

Перший (основний) варіант наводиться одразу після тексту статті, джерела подаються в алфавітному порядку. Список літератури наводиться латиницею. Джерела українською та російською мовами наводяться у перекладі на англійську мову, але так, як вони показані та реєструються на англійських сторінках сайтів журналів. Якщо джерело не має аналога назви на англійській мові - воно наводиться у транслітерації. Таке оформлення списку літератури необхідне для аналізу статті та посилань на авторів у міжнародних наукометричних базах даних, підвищення індексу цитування авторів.

Другий варіант повторює перший, але джерела українською та російською мовами подаються в оригінальній формі. Цей варіант необхідний для оформлення електронних версій журналу на українській і російській сторінках, цитованості у кирилічних наукометричних базах.

\section{Журнальна публікащія}

\section{Приклади оформлення джерел літератури}

Author AA, Author BB, Author CC. (2005). Title of the article. Title of Journal. 10(2);3:49-53.

Книжка

Author AA, Author BB, Author CC. (2006). Titile of the book. Sity: Publisher: 256.

Розділ у книжиі

Author AA, Author BB, Author CC. (2006). Titile of the chapter(s) of the book. In book Author(s). Titile of the book. Eds. Name. Sity: Publisher: 256.

Інтернет-ресурс

Author AA, Author BB, Author CC. (2006). Titile of article. Title of Journal/book. URL-adress. 